\title{
Biological Aspects of Aggression and Violence in Schizophrenia
}

\author{
WonKyung Cho', Won-Suk Shin ${ }^{1}$, Iseul $\mathrm{An}^{2,3}$, Minji Bang ${ }^{3}$, Doo-Yeoun Cho ${ }^{1}$, Sang-Hyuk Lee ${ }^{1,3}$ \\ ${ }^{1}$ Department of Clinical Pharmacology and Therapeutics, CHA Bundang Medical Center, CHA University School of Medicine, ${ }^{2}$ Clinical \\ Counseling Psychology Graduate School, CHA University, ${ }^{3}$ Department of Psychiatry, CHA Bundang Medical Center, CHA University School \\ of Medicine, Seongnam, Korea
}

\begin{abstract}
Although the majority of patients with schizophrenia are not actually violent, an increased tendency toward violent behaviors is known to be associated with schizophrenia. There are several factors to consider when identifying the subgroup of patients with schizophrenia who may commit violent or aggressive acts. Comorbidity with substance abuse is the most important clinical indicator of increased aggressive behaviors and crime rates in patients with schizophrenia. Genetic studies have proposed that polymorphisms in the promoter region of the serotonin transporter gene and in the catechol-O-methyltransferase gene are related to aggression. Neuroimaging studies have suggested that fronto-limbic dysfunction may be related to aggression or violence. By identifying specific risk factors, a more efficient treatment plan to prevent violent behavior in schizophrenia will be possible. Management of comorbid substance use disorder may help prevent violent events and overall aggression. Currently, clozapine may be the only effective antipsychotic medication to repress aggressive behavior. With the current medical field moving toward tailored medicine, it is important to identify vulnerable schizophrenia populations and provide efficient treatment.
\end{abstract}

KEY WORDS: Aggression; Violence; Schizophrenia; Neuroimaging; Antipsychotic agents.

\section{INTRODUCTION}

The prevalence of major mental disorders is higher in prisoners than in the general population [1-3]. Crime rates, especially for violent offenses, are more highly correlated with psychiatric disorders [4,5]. Moreover, prisoners with mental health issues are more likely to violate prison rules and be involved in prison infractions and violent incidents [6-9].

Individuals with schizophrenia are 4 to 7 times more likely to commit violent crimes, such as assault and homi-

\footnotetext{
Received: May 7, 2019 / Revised: July 1, 2019

Accepted: July 2, 2019

Address for correspondence: Sang-Hyuk Lee

Department of Psychiatry, CHA Bundang Medical Center, CHA

University School of Medicine, 59 Yatap-ro, Bundang-gu,

Seongnam 13496, Korea

E-mail: leesanghyuk@yahoo.com

ORCID: https://orcid.org/0000-0001-7939-3000

Doo-Yeoun Cho

Department of Clinical Pharmacology and Therapeutics, CHA

Bundang Medical Center, CHA University School of Medicine, 59

Yatap-ro, Bundang-gu, Seongnam 13496, Korea

E-mail: dooycho@cha.ac.kr

ORCID: https://orcid.org/0000-0003-2996-1000
}

cide [4,5], and 4 to 6 times more likely to exhibit general aggressive behavior, such as verbal and physical threats $[10,11]$, compared with the general population. Despite reports from several large cohort studies indicating an increase in violent behavior in schizophrenia $[4,10,12,13]$, some debate remains on the association between violent behavior and the disorder. One prospective study showed no significant difference in the prevalence of violence between the general population and patients with schizophrenia [14]. Several studies have shown minimal increase in hostile behavior in schizophrenia when comorbidity for substance abuse was considered as a confounding factor $[14,15]$. The lack of consensus among studies is attributable to the absence of uniform variables such as substance abuse, dysfunctional childhood, and positive symptoms of psychosis. A better understanding of the confounding factors associated with violent behavior and schizophrenia is needed. Thus, if the confounding factor is modifiable, specific treatment guidelines can be drafted to manage modifiable risk in patients with schizophrenia. Furthermore, identifying specific risk factors for violence allows clinicians to diagnose those who may

(ㄷ) This is an Open-Access article distributed under the terms of the Creative Commons Attribution Non-Commercial License (http://creativecommons.org/licenses/by-nc/4.0) which permits unrestricted non-commercial use, distribution, and reproduction in any medium, provided the original work is properly cited. 
need closer management for early violence prevention. Predicting a patient's future conduct may cause stigmatization. Thus, structural and objective guidance measures of risk assessment, such as biological markers, are optimal.

Herein, we review the social and biological markers for violence and briefly assess the current management of patients with schizophrenia who exhibit aggressive behavior.

\section{SCHIZOPHRENIA AND SUBSTANCE ABUSE}

Current American Psychiatric Association guidelines indicate that identifying risk factors for violence and assessment of dangerousness should be part of the standard psychiatric evaluation [16]. Currently, there is no established tool to assess the risk factors of aggression in patients with schizophrenia. Previous studies have shown that substance abuse, alcohol abuse, neurological impairment, and social burdens increase risk of aggressive behavior (Table 1) [12,13,15,17-26]. Among the multiple risk factors, comorbid substance abuse and presence of positive symptoms, such as persecutory ideation, have been duplicated in several studies $[13,19]$. Patients with schizophrenia with comorbid substance abuse not only have more overt aggression, as measured with overt aggression scales, but have higher criminal conviction rates (odd ratio [OR] 2.35-16.1), and having more than one substance abuse exacerbates violent behavior [20].

These findings are of great clinical concern because the lifetime prevalence of comorbid substance abuse is nearly $60 \%$ in patients with schizophrenia $[17,27]$. Substance dependence is five times more prevalent in patients with schizophrenia than in the general population. Several hypotheses have attempted to explain the mechanism behind this phenomenon. Most antipsychotic medications block dopamine receptor D2 (D2R) that interfere with dopamine neurotransmission in the whole brain. Patients may resort to drugs of abuse to counteract the cognitive deficits induced by pre-frontal D2R blockage and compensate for the anhedonia induced by D2R blockade in the nucleus accumbens and ventral pallidum [27]. Reduction in dopamine D2 receptor has also been associated with enhanced impulsivity and reinforcement of drug use $[21,27]$. Overlap in genes between schizophrenia and addiction, including neuregulin 1, catechol-O-methyltransferase, $v$-akt murine thymoma viral oncogene homolog 1 , monoamine oxidase $\mathrm{A}$ (MAOA), and neurexin 1 and 3, suggests a genetic vulnerability to the comorbidity. However, Fazel et al. [21] found that patients who had been diagnosed with substance abuse after being diagnosed with schizophrenia posed higher risk (OR 6.4) than those who had been diagnosed with substance abuse prior to being diagnosed with schizophrenia (OR 1.9). Whether a shared genetic susceptibility to substance abuse and schizophrenia increases violent behavior or schizophrenia leads to substance abuse that results in violent behavior is still in question.

The shared genetic susceptibility of substance abuse and schizophrenia suggests the correlation between aggressive behavior and schizophrenia may be due to substance abuse. Impulsivity, aggression, and substance abuse disorders share neurobiological commonalities [30]. Among criminal offenders, individuals with substance abuse have more judicial problems, including higher recidivism and more violent behavior in detention, which may possibly be due to the high impulsivity and aggressiveness found in this population [31]. Future studies should examine the correlation between the overlapping genes of substance abuse and schizophrenia with aggression.

Attributing aggressive behavior solely to schizophrenia may be misguided. Specific risk factors, such as substance abuse, should be targeted in the management of aggressive behavior exhibited by patients with schizophrenia. Treating the comorbid substance abuse may reduce violent behavior in these patients. Furthermore, future studies should be conducted to determine whether there is a clear causative relationship between comorbid substance abuse and violent behavior.

\section{TESTOSERONE LEVEL IN SCHIZOPHRENIA}

Numerous studies have shown a positive correlation between testosterone level and aggressive behavior and criminality in the general population and in patients with personality disorder [32-36]. However, no association has been found between criminal behavior and testosterone level in patients with schizophrenia [36]. In fact, one study found that low-normal testosterone level is significantly associated with more severe hostility symptoms in men with schizophrenia [37]. This finding is particularly interesting because several studies have found significantly lower levels of serum testosterone in men with schizophrenia during acute psychotic episodes but gen- 


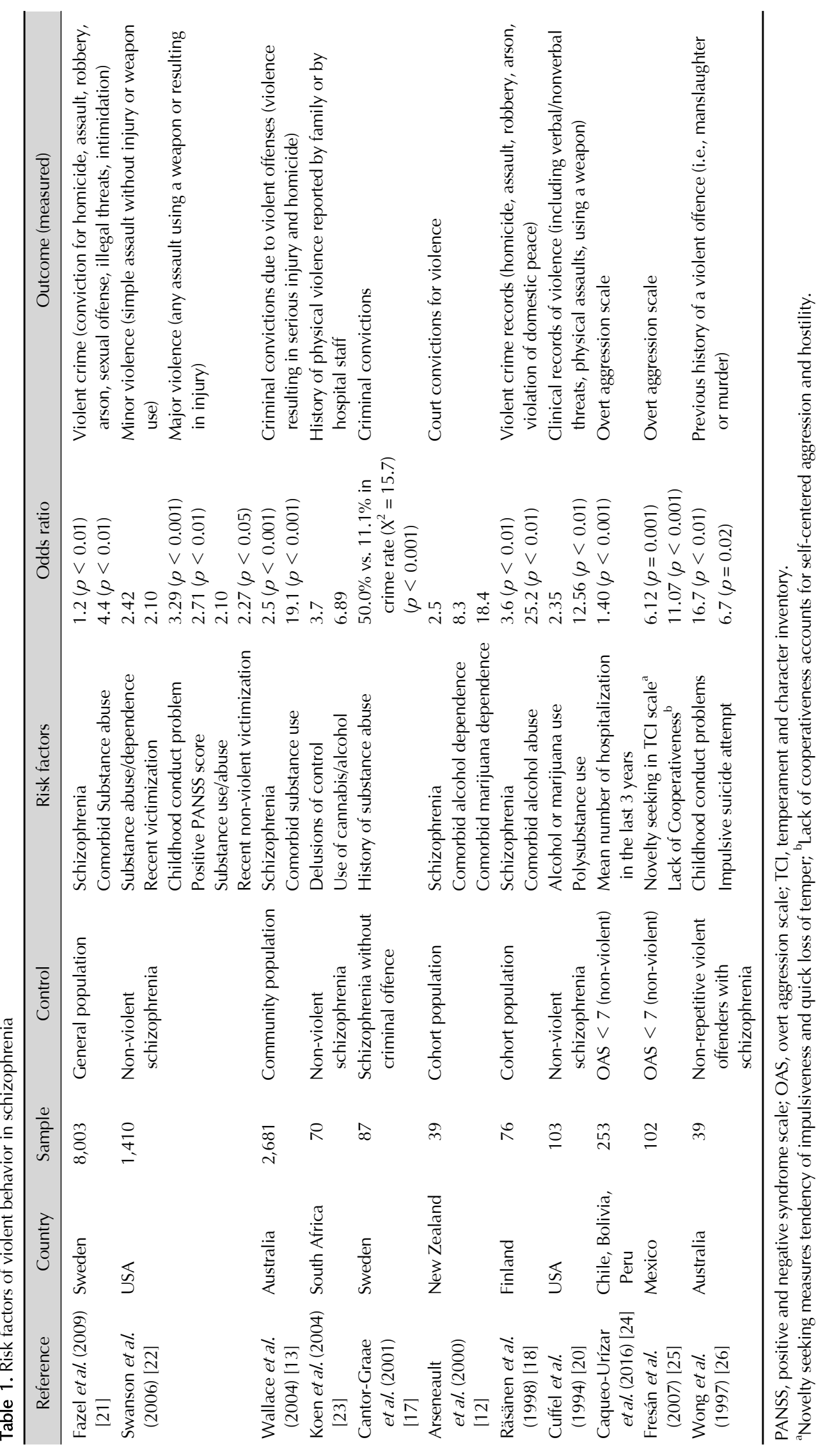


erally not during the maintenance phase [38-40]. The above findings suggest an association between acute psychotic episodes and lower testosterone level. However, another study showed no correlation between testosterone level and degree or type of aggression [41].

Many studies have attributed the low levels of testosterone found in patients with schizophrenia to the chronic use of antipsychotics [36]. Antipsychotics increase the risk of diabetes, and diabetes is associated with low testosterone concentrations $[42,43]$. In the short-term, antipsychotics, such as haloperidol, suppress serum testosterone [44]. However low testosterone is found in antipsychotic-naive patients with schizophrenia, suggesting a disease component to reduced testosterone levels [45]. Further study is needed to assess the negative correlation between testosterone and aggression in newly diagnosed schizophrenia to confound for chronic antipsychotic use.

\section{GENETIC MARKERS OF AGGRESSION IN SCHIZOPHRENIA}

Genetic background is estimated to account for $50 \%$ of human aggression [46]. Numerous studies have investigated the gene responsible for aggression in schizophrenia. The genes responsible for regulating the serotonergic and catecholaminergic systems are considered key genes. Several studies have shown reduction in cerebrospinal fluid levels of serotonin metabolite 5-hydroxyindoleacetic acid in aggressive males with deviant behavior [47-49]. However, genetic studies on serotonin transporter have identified no significant association between aggression and schizophrenia [50,51]. Catechol-O-methyltransferase and MAOA genes encoding for enzymes responsible for catabolism of catecholamine have also been explored. Catechol-O-methyltransferase and MAOA knockout mice showed elevated aggression [52]. Studies have shown varied results, partly due to different sample populations and varying measures of aggression (Table 2) [23,50,51,53-70]. The most recent meta-analysis found no association between any polymorphism and aggression and did not provide any evidence supporting the use of genetic markers for risk prediction and management of aggression in schizophrenia patients [71]. However, this analysis cannot be considered conclusive because sample sizes used in the review were small. Moreover, a complex behavior such as aggression is likely to be mediated by complex interaction among many genes, as opposed to what single polymorphism studies have been trying to pinpoint. Future studies examining the genetic association between aggression and schizophrenia using alternative study designs are needed.

\section{NEUROIMAGING FINDINGS REGARDING AGGRESSION AND VIOLENCE IN SCHIZOPHRENIA}

Abnormalities in various parts of the brain have been associated with increased aggression with no single brain area acting as a key region. Hoptman and Antonius [72] found that frontal and temporal abnormalities were associated with aggression in schizophrenia. Several other studies have found that different brain regions influence violence in schizophrenia (Table 3) [26,73-86]. Aggression control is multifaceted, and dysfunction in functional connectivity between the amygdala and prefrontal cortex tends to predict higher levels of aggression $[73,74]$. The most consistent findings from the structural studies were reduced volumes of the hippocampus and the frontal lobe (in particular, the orbitofrontal and anterior cingulate cortex) in patients with schizophrenia with a history of violence or higher aggression scores. These findings suggest that dysfunctions of fronto-limbic regions in schizophrenia can be associated with aggression or violence. However, the neuroimaging findings of aggression and violence were methodologically heterogeneous, with four particular areas of concern: different definitions of violence, region of interest versus whole-brain studies, small subject samples, and group comparisons in a heterogeneous diagnostic category [87].

\section{MANAGEMENT OF AGGRESSION IN SCHIZOPHRENIA}

Antipsychotic treatment significantly reduces aggression in patients with schizophrenia [88]. However, who should receive treatment and which drugs should be administered are still under debate. Because no specific biomarkers or pharmacogenetic tests are available to guide treatment choice, treatment is still chosen based on broad guidelines and is not personalized.

The overwhelming opinion in the past was that atypical antipsychotics, such as clozapine, risperidone, quetia- 


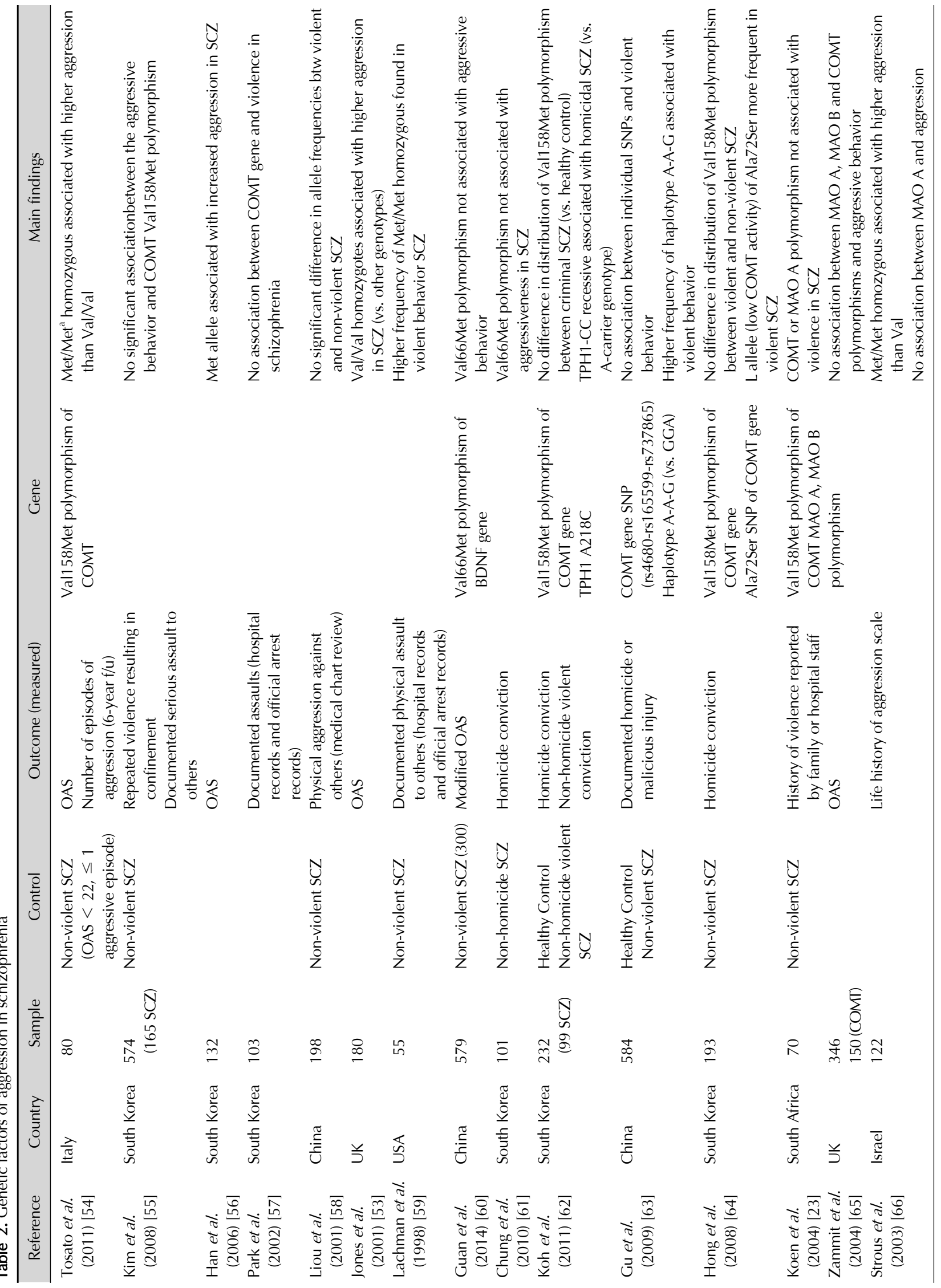




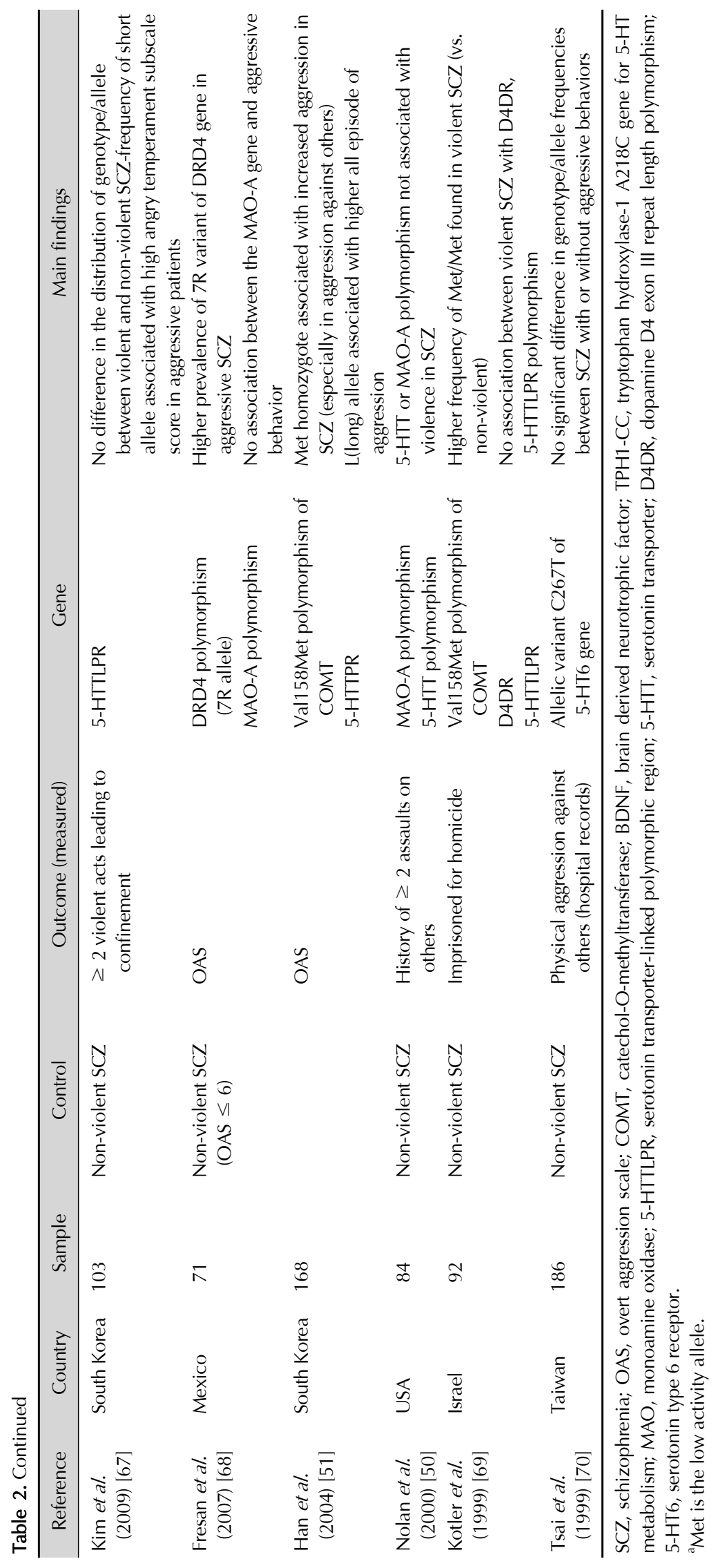




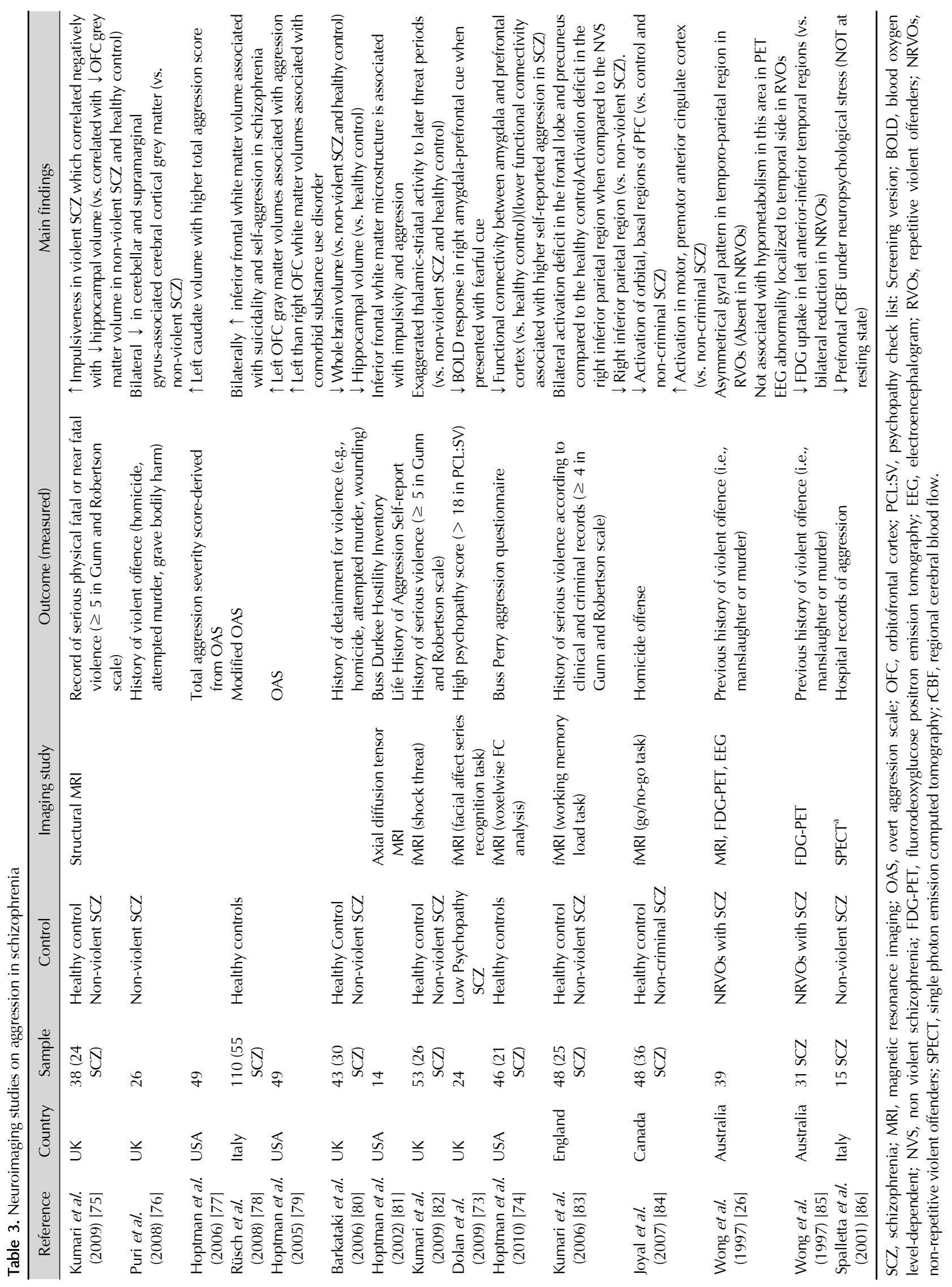


pine, and ziprasidone, were the most effective drugs in the treatment of patients with aggression and violent behavior [89-91]. However, two large double-blind trials found no advantage to the use of second-generation antipsychotics in treating chronic schizophrenia, thereby questioning its true effectiveness [53,92]. There is still mixed evidence showing clozapine and olanzapine are more effective than haloperidol; however, the same study shows perphenazine, a first-generation drug, is more effective than haloperidol as well [93]. Another study using data from the Clinical Antipsychotic Trials of Intervention Effectiveness project also did not find any advantage to the use of second-generation antipsychotics in violence risk reduction, compared with perphenazine [88]. However, that study did not include treatment response to clozapine, the most effective drug in reducing aggression in patients with schizophrenia [90,94-96].

Although mixed results question the use of atypical antipsychotics as first-line treatment for schizophrenia, clozapine may still be the most effective drug in reducing aggression. The exact mechanism of clozapine's anti-aggressive effect is not yet understood, but the effect seems to be independent of the sedative and antipsychotic effect of the drug [97]. Moreover, little improvement has been made in antipsychotics since clozapine in the 1950s. Expert consensus guideline [98] has recommended the use of clozapine and risperidone as first-line treatments for chronic aggression. Despite this recommendation, clozapine is rarely used as a first-line treatment because of its hematological side effects. Burdensome full blood count monitoring is required throughout the treatment. Such tedious monitoring may increase the already high non-adherence seen in schizophrenia [99]. When administering clozapine, interventions including medication education, psychoeducation, and motivational interviewing techniques should be utilized to increase compliance [100].

Treatment of substance use disorder may also be helpful in managing aggressive behavior in patients with schizophrenia. Second-generation antipsychotics, such as clozapine and risperidone, have been found to reduce the drive to self-medicate the negative symptoms [101] and not to have the side effects of typical antipsychotics, allowing for better control for substance use. Moreover, low striatal dopamine is associated with neuroleptic-induced dysphoria and with vulnerability to addiction. Choosing an antipsychotic medication that is a weak dopamine D2 blocker will avoid further compromising dopamine striatal functioning, thus reducing the possibility of addictive behavior [102]

\section{CONCLUSION}

Identification of risk factors should provide a basis for a management plan and not a means of labeling a patient as pre-delinquent, especially because aggression significantly decreases under treatment [88]. Despite efforts to find biological, genetic markers associated with aggression in schizophrenia, no consistent findings have been established to explain violent and aggressive behavior in schizophrenia. Further study is needed before any discussion on using such markers to predict patient behavior.

Among multiple risk factors, comorbid substance abuse has repeatedly been found to be associated with aggressive behavior. Patients with schizophrenia without comorbid substance abuse have only a slight increased risk of violent crime compared with the general population, suggesting that substance abuse plays a mediating role. Whether aggressive behavior in schizophrenia can solely be attributed to comorbid substance abuse or whether a specific underlying gene results in both the aggression and comorbid substance abuse in schizophrenia requires further study. Nonetheless, treating the comorbid substance abuse is necessary in managing violent behavior in patients with schizophrenia.

With the increasing perception that patients undergoing psychiatric treatment are dangerous, precariously identifying risk factors can exacerbate this notion.

\section{- Conflicts of Interest}

No potential conflict of interest relevant to this article was reported.

\section{- Author Contributions}

Study design: WonKyung Cho, Won-Suk Shin, Minji Bang, Doo-Yeoun Cho, Sang-Hyuk Lee. Data review, interpretation and manuscript preparation: WonKyung Cho, Won-Suk Shin, Minji Bang, Doo-Yeoun Cho, Sang-Hyuk Lee. Writing-original draft: WonKyung Cho, Won-Suk Shin, Doo-Yeoun Cho, Sang-Hyuk Lee. Writing-review \& editing: Iseul An, Doo-Yeoun Cho, Sang-Hyuk Lee. Supervision: Doo-Yeoun Cho, Sang-Hyuk Lee. 


\section{ORCID}

WonKyung Cho

https://orcid.org/0000-0002-0290-8667

Won-Suk Shin https://orcid.org/0000-0002-6163-5726

Iseul An https://orcid.org/0000-0003-4008-0730

Minji Bang https://orcid.org/0000-0002-1669-4014

Doo-Yeoun Cho https://orcid.org/0000-0003-2996-1000

Sang-Hyuk Lee

\section{REFERENCES}

1. Brown SR, Fernandez C, Bertellotti R, Asensio JA. Blunt rupture of the thoracic duct after severe thoracic trauma. Trauma Surg Acute Care Open 2018;3:e000183.

2. Prins SJ. Prevalence of mental illnesses in US State prisons: a systematic review. Psychiatr Serv 2014; 65:862-872.

3. Fazel S, Hayes AJ, Bartellas K, Clerici M, Trestman R. Mental health of prisoners: prevalence, adverse outcomes, and interventions. Lancet Psychiatry 2016;3:871-881.

4. Tiihonen J, Isohanni $M$, Räsänen $P$, Koiranen $M$, Moring J. Specific major mental disorders and criminality: a 26-year prospective study of the 1966 northern Finland birth cohort. Am J Psychiatry 1997; 154:840-845.

5. Lindqvist P, Allebeck P. Schizophrenia and crime. A longitudinal follow-up of 644 schizophrenics in Stockholm. Br J Psychiatry 1990;157:345-350.

6. Schenk AM, Fremouw WJ. Individual characteristics related to prison violence: a critical review of the literature. Aggress Violent Behav 2012;17:430-442.

7. Houser KA, Welsh W. Examining the association between co-occurring disorders and seriousness of misconduct by female prison inmates. Crim Justice Behav 2014;41:650-666.

8. James DJ, Glaze LE. Mental health problems of prison and jail inmates. Washington, DC:US Department of Justice; 2006.

9. Hassan L, Birmingham L, Harty MA, Jarrett M, Jones P, King C, et al. Prospective cohort study of mental health during imprisonment. Br J Psychiatry 2011;198:37-42.

10. Christian CJ, Jean-Luc D, Catherine G, Frederic M. Major mental disorders and violence: a critical update. Curr Psychiatry Rev 2007;3:33-50.

11. Kooyman I, Dean K, Harvey S, Walsh E. Outcomes of public concern in schizophrenia. Br J Psychiatry Supp/ 2007;50: s29-s36.

12. Arseneault L, Moffitt TE, Caspi A, Taylor PJ, Silva PA. Mental disorders and violence in a total birth cohort: results from the Dunedin Study. Arch Gen Psychiatry 2000;57:979-986.

13. Wallace C, Mullen PE, Burgess P. Criminal offending in schizophrenia over a 25-year period marked by deinstitutionalization and increasing prevalence of comorbid substance use disorders. Am J Psychiatry 2004;161:716727.

14. Steadman HJ, Mulvey EP, Monahan J, Robbins PC, Appelbaum PS, Grisso T, et al. Violence by people discharged from acute psychiatric inpatient facilities and by others in the same neighborhoods. Arch Gen Psychiatry 1998;55:393-401.

15. Fazel $\mathrm{S}$, Långström $\mathrm{N}$, Hjern $\mathrm{A}$, Grann $\mathrm{M}$, Lichtenstein $\mathrm{P}$. Schizophrenia, substance abuse, and violent crime. JAMA 2009;301:2016-2023.

16. Lehman AF, Lieberman JA, Dixon LB, McGlashan TH, Miller $\mathrm{AL}$, Perkins DO, et al. Practice guideline for the treatment of patients with schizophrenia, second edition. Am J Psychiatry 2004;161(2 Suppl):1-56.

17. Cantor-Graae E, Nordström LG, McNeil TF. Substance abuse in schizophrenia: a review of the literature and a study of correlates in Sweden. Schizophr Res 2001;48:69-82.

18. Räsänen $P$, Tiihonen J, Isohanni $M$, Rantakallio $P$, Lehtonen J, Moring J. Schizophrenia, alcohol abuse, and violent behavior: a 26-year followup study of an unselected birth cohort. Schizophr Bull 1998;24:437-441.

19. Krakowski M, Czobor P, Chou JC. Course of violence in patients with schizophrenia: relationship to clinical symptoms. Schizophr Bull 1999;25:505-517.

20. Cuffel BJ, Shumway M, Chouljian TL, MacDonald T. A longitudinal study of substance use and community violence in schizophrenia. J Nerv Ment Dis 1994;182:704-708.

21. Fazel S, Gulati G, Linsell L, Geddes JR, Grann M. Schizophrenia and violence: systematic review and meta-analysis. PLoS Med 2009;6:e1000120.

22. Swanson JW, Swartz MS, Van Dorn RA, Elbogen EB, Wagner $\mathrm{HR}$, Rosenheck RA, et al. A national study of violent behavior in persons with schizophrenia. Arch Gen Psychiatry 2006; 63:490-499.

23. Koen L, Kinnear CJ, Corfield VA, Emsley RA, Jordaan E, Keyter $\mathrm{N}$, et al. Violence in male patients with schizophrenia: risk markers in a South African population. Aust N ZJ Psychiatry 2004;38:254-259.

24. Caqueo-Urízar A, Fond G, Urzúa A, Boyer L, Williams DR. Violent behavior and aggression in schizophrenia: prevalence and risk factors. A multicentric study from three Latin-America countries. Schizophr Res 2016;178:23-28.

25. Fresán A, Apiquian R, Nicolini H, Cervantes JJ. Temperament and character in violent schizophrenic patients. Schizophr Res 2007;94:74-80.

26. Wong $M$, Fenwick $P$, Fenton $G$, Lumsden J, Maisey $M$, Stevens J. Repetitive and non-repetitive violent offending behaviour in male patients in a maximum security mental hospital--clinical and neuroimaging findings. Med Sci Law 1997;37:150-160.

27. Volkow ND. Substance use disorders in schizophrenia-clinical implications of comorbidity. Schizophr Bull 2009; 35:469-472.

28. Dalley JW, Fryer TD, Brichard L, Robinson ES, Theobald DE, Lääne K, et al. Nucleus accumbens D2/3 receptors predict 
trait impulsivity and cocaine reinforcement. Science 2007; 315:1267-1270.

29. Everitt BJ, Belin D, Economidou D, Pelloux Y, Dalley JW, Robbins TW. Review. Neural mechanisms underlying the vulnerability to develop compulsive drug-seeking habits and addiction. Philos Trans $R$ SOC Lond B Biol SCi 2008; 363:3125-3135.

30. Brady KT, Myrick H, McElroy S. The relationship between substance use disorders, impulse control disorders, and pathological aggression. Am J Addict 1998;7:221-230.

31. Cuomo C, Sarchiapone M, Giannantonio MD, Mancini M, Roy A. Aggression, impulsivity, personality traits, and childhood trauma of prisoners with substance abuse and addiction. Am J Drug Alcohol Abuse 2008;34:339-345.

32. Sánchez-Martín JR, Fano E, Ahedo L, Cardas J, Brain PF, Azpíroz A. Relating testosterone levels and free play social behavior in male and female preschool children. Psychoneuroendocrinology 2000;25:773-783.

33. van Bokhoven I, van Goozen SH, van Engeland H, Schaal B, Arseneault L, Séguin JR, et al. Salivary testosterone and aggression, delinquency, and social dominance in a population-based longitudinal study of adolescent males. Horm Behav 2006;50:118-125.

34. Dabbs JM Jr, Jurkovic GJ, Frady RL. Salivary testosterone and cortisol among late adolescent male offenders. J Abnorm Child Psychol 1991; 19:469-478.

35. Booth A, Osgood DW. The influence of testosterone on deviance in adulthood: assessing and explaining the relationship*. Criminol 1993;31:93-117.

36. Räsänen $P$, Hakko $H$, Visuri $S$, Paanila J, Kapanen $P$, Suomela $\mathrm{T}$, et al. Serum testosterone levels, mental disorders and criminal behaviour. Acta Psychiatr Scand 1999;99:348352.

37. Moore L, Kyaw M, Vercammen A, Lenroot R, Kulkarni J, Curtis J, et al. Serum testosterone levels are related to cognitive function in men with schizophrenia. Psychoneuroendocrinology 2013;38:1717-1728.

38. Taherianfard M, Shariaty M. Evaluation of serum steroid hormones in schizophrenic patients. Indian J Med Sci 2004;58: 3-9.

39. Huber TJ, Tettenborn C, Leifke E, Emrich HM. Sex hormones in psychotic men. Psychoneuroendocrinology 2005;30: 111-114.

40. $\mathrm{Ko} \mathrm{YH}$, Jung $\mathrm{SW}$, Joe $\mathrm{SH}$, Lee $\mathrm{CH}$, Jung $\mathrm{HG}$, Jung $\mathrm{IK}$, et al. Association between serum testosterone levels and the severity of negative symptoms in male patients with chronic schizophrenia. Psychoneuroendocrinology 2007;32:385-391.

41. Sisek-Šprem M, Križaj A, Jukić V, Milošević M, Petrović Z, Herceg M. Testosterone levels and clinical features of schizophrenia with emphasis on negative symptoms and aggression. Nord I Psychiatry 2015;69:102-109.

42. Saad $\mathrm{F}$, Gooren $\mathrm{L}$. The role of testosterone in the metabolic syndrome: a review. J Steroid Biochem Mol Biol 2009;114:
40-43.

43. Goncharov NP, Katsya GV, Chagina NA, Gooren LJ. Three definitions of metabolic syndrome applied to a sample of young obese men and their relation with plasma testosterone. Aging Male 2008;11:118-122.

44. Okonmah AD, Bradshaw WG, Couceyro P, Soliman KF. The effect of neuroleptic drugs on serum testosterone level in the male rat. Gen Pharmacol 1986;17:235-238.

45. Fernandez-Egea E, García-Rizo C, Miller B, Parellada E, Justicia A, Bernardo M, et al. Testosterone in newly diagnosed, antipsychotic-naive men with nonaffective psychosis: a test of the accelerated aging hypothesis. Psychosom Med 2011;73:643-647.

46. Miles DR, Carey G. Genetic and environmental architecture of human aggression. J Pers Soc Psychol 1997;72:207-217.

47. Higley JD, Mehlman PT, Poland RE, Taub DM, Vickers J, Suomi SJ, et al. CSF testosterone and 5-HIAA correlate with different types of aggressive behaviors. Biol Psychiatry 1996; 40:1067-1082.

48. Birger M, Swartz M, Cohen D, Alesh Y, Grishpan C, Kotelr M. Aggression: the testosterone-serotonin link. Isr Med Assoc J 2003; 5:653-658.

49. Coccaro EF, Kavoussi RJ, Trestman RL, Gabriel SM, Cooper TB, Siever LJ. Serotonin function in human subjects: intercorrelations among central 5-HT indices and aggressiveness. Psychiatry Res 1997;73:1-14.

50. Nolan KA, Volavka J, Lachman HM, Saito T. An association between a polymorphism of the tryptophan hydroxylase gene and aggression in schizophrenia and schizoaffective disorder. Psychiatr Genet 2000;10:109-115.

51. Han DH, Park DB, Na C, Kee BS, Lee YS. Association of aggressive behavior in Korean male schizophrenic patients with polymorphisms in the serotonin transporter promoter and catecholamine-O-methy/transferase genes. Psychiatry Res 2004; 129:29-37.

52. Volavka J, Bilder R, Nolan K. Catecholamines and aggression: the role of COMT and MAO polymorphisms. Ann NY Acad Sci 2004;1036:393-398.

53. Jones PB, Barnes TR, Davies L, Dunn G, Lloyd H, Hayhurst $\mathrm{KP}$, et al. Randomized controlled trial of the effect on Quality of Life of second- vs first-generation antipsychotic drugs in schizophrenia: Cost Utility of the Latest Antipsychotic Drugs in Schizophrenia Study (CUtLASS 1). Arch Gen Psychiatry 2006;63:1079-1087.

54. Tosato S, Bonetto C, Di Forti M, Collier D, Cristofalo D, Bertani $\mathrm{M}$, et al. Effect of COMT genotype on aggressive behaviour in a community cohort of schizophrenic patients. Neurosci Lett 2011;495:17-21.

55. Kim YR, Kim JH, Kim SJ, Lee D, Min SK. Catechol-O-methyltransferase Val158Met polymorphism in relation to aggressive schizophrenia in a Korean population. Eur Neuropsychopharmacol 2008;18:820-825.

56. Han DH, Kee BS, Min KJ, Lee YS, Na C, Park DB, et al. Effects 
of catechol-O-methyltransferase Val158Met polymorphism on the cognitive stability and aggression in the first-onset schizophrenic patients. Neuroreport 2006; 17:95-99.

57. Park TW, Yoon KS, Kim JH, Park WY, Hirvonen A, Kang D. Functional catechol-O-methyltransferase gene polymorphism and susceptibility to schizophrenia. Eur Neuropsychopharmacol 2002;12:299-303.

58. Liou YJ, Tsai SJ, Hong CJ, Wang YC, Lai IC. Association analysis of a functional catechol-o-methyltransferase gene polymorphism in schizophrenic patients in Taiwan. Neuropsychobiology 2001;43:11-14.

59. Lachman HM, Nolan KA, Mohr P, Saito T, Volavka J. Association between catechol O-methyltransferase genotype and violence in schizophrenia and schizoaffective disorder. Am I Psychiatry 1998; 155:835-837.

60. Guan X, Dong ZQ, Tian YY, Wu LN, Gu Y, Hu ZQ, et al. Lack of association between brain-derived neurotrophic factor Val66Met polymorphism and aggressive behavior in schizophrenia. Psychiatry Res 2014;215:244-245.

61. Chung S, Chung HY, Jung J, Chang JK, Hong JP. Association among aggressiveness, neurocognitive function, and the Val66Met polymorphism of brain-derived neurotrophic factor gene in male schizophrenic patients. Compr Psychiatry 2010;51:367-372.

62. Koh KB, Choi EH, Lee YJ, Han M, Choi SS, Kim SW, et al. The relation of serotonin-related gene and COMT gene polymorphisms with criminal behavior in schizophrenic disorder. J Clin Psychiatry 2012;73:159-163.

63. Gu Y, Yun L, Tian Y, Hu Z. Association between COMT gene and Chinese male schizophrenic patients with violent behavior. Med Sci Monit 2009;15:CR484-CR489.

64. Hong JP, Lee JS, Chung S, Jung J, Yoo HK, Chang SM, et al. New functional single nucleotide polymorphism (Ala72Ser) in the COMT gene is associated with aggressive behavior in male schizophrenia. Am J Med Genet B Neuropsychiatr Genet 2008;147B:658-660.

65. Zammit S, Jones G, Jones SJ, Norton N, Sanders RD, Milham $\mathrm{C}$, et al. Polymorphisms in the MAOA, MAOB, and COMT genes and aggressive behavior in schizophrenia. Am J Med Genet B Neuropsychiatr Genet 2004;128B:19-20.

66. Strous RD, Nolan KA, Lapidus R, Diaz L, Saito T, Lachman $\mathrm{HM}$. Aggressive behavior in schizophrenia is associated with the low enzyme activity COMT polymorphism: a replication study. Am / Med Genet B Neuropsychiatr Genet 2003;120B:29-34.

67. Kim YR, Jahng JW, Min SK. Association between the serotonin transporter gene (5-HTTLPR) and anger-related traits in Korean schizophrenic patients. Neuropsychobiology 2009; 59:165-171.

68. Fresan A, Camarena B, Apiquian R, Aguilar A, Urraca N, Nicolini $\mathrm{H}$. Association study of MAO-A and DRD4 genes in schizophrenic patients with aggressive behavior. Neuropsychobiology 2007;55:171-175.
69. Kotler M, Barak P, Cohen H, Averbuch IE, Grinshpoon A, Gritsenko I, et al. Homicidal behavior in schizophrenia associated with a genetic polymorphism determining low catechol O-methyltransferase (COMT) activity. Am J Med Genet 1999;88:628-633.

70. Tsai SJ, Chiu HJ, Wang YC, Hong CJ. Association study of serotonin-6 receptor variant (C267T) with schizophrenia and aggressive behavior. Neurosci Lett 1999;271:135-137.

71. Vassos E, Collier DA, Fazel S. Systematic meta-analyses and field synopsis of genetic association studies of violence and aggression. Mol Psychiatry 2014;19:471-477.

72. Hoptman MJ, Antonius D. Neuroimaging correlates of aggression in schizophrenia: an update. Curr Opin Psychiatry 2011;24:100-106.

73. Dolan MC, Fullam RS. Psychopathy and functional magnetic resonance imaging blood oxygenation level-dependent responses to emotional faces in violent patients with schizophrenia. Biol Psychiatry 2009;66:570-577.

74. Hoptman MJ, D’Angelo D, Catalano D, Mauro CJ, Shehzad ZE, Kelly AM, et al. Amygdalofrontal functional disconnectivity and aggression in schizophrenia. Schizophr Bull 2010; 36:1020-1028.

75. Kumari V, Barkataki I, Goswami S, Flora S, Das M, Taylor P. Dysfunctional, but not functional, impulsivity is associated with a history of seriously violent behaviour and reduced orbitofrontal and hippocampal volumes in schizophrenia. Psychiatry Res 2009; 173:39-44.

76. Puri BK, Counsell SJ, Saeed N, Bustos MG, Treasaden IH, Bydder GM. Regional grey matter volumetric changes in forensic schizophrenia patients: an MRI study comparing the brain structure of patients who have seriously and violently offended with that of patients who have not. BMC Psychiatry 2008;8 Supp/ 1:S6.

77. Hoptman MJ, Volavka J, Czobor P, Gerig G, Chakos M, Blocher J, et al. Aggression and quantitative MRI measures of caudate in patients with chronic schizophrenia or schizoaffective disorder. I Neuropsychiatry Clin Neurosci 2006; 18:509-515.

78. Rüsch N, Spoletini I, Wilke M, Martinotti G, Bria P, Trequattrini A, et al. Inferior frontal white matter volume and suicidality in schizophrenia. Psychiatry Res 2008;164:206214.

79. Hoptman MJ, Volavka J, Weiss EM, Czobor P, Szeszko PR, Gerig G, et al. Quantitative MRI measures of orbitofrontal cortex in patients with chronic schizophrenia or schizoaffective disorder. Psychiatry Res 2005;140:133-145.

80. Barkataki I, Kumari V, Das M, Taylor P, Sharma T. Volumetric structural brain abnormalities in men with schizophrenia or antisocial personality disorder. Behav Brain Res 2006; 169:239-247.

81. Hoptman MJ, Volavka J, Johnson G, Weiss E, Bilder RM, Lim KO. Frontal white matter microstructure, aggression, and impulsivity in men with schizophrenia: a preliminary study. 
Biol Psychiatry 2002;52:9-14.

82. Kumari V, Das M, Taylor PJ, Barkataki I, Andrew C, Sumich A, et al. Neural and behavioural responses to threat in men with a history of serious violence and schizophrenia or antisocial personality disorder. Schizophr Res 2009;110:47-58.

83. Kumari V, Aasen I, Taylor P, Ffytche DH, Das M, Barkataki I, et al. Neural dysfunction and violence in schizophrenia: an fMRI investigation. Schizophr Res 2006;84:144-164.

84. Joyal CC, Putkonen A, Mancini-Marïe A, Hodgins S, Kononen $\mathrm{M}$, Boulay $\mathrm{L}$, et al. Violent persons with schizophrenia and comorbid disorders: a functional magnetic resonance imaging study. Schizophr Res 2007;91:97-102.

85. Wong MT, Fenwick PB, Lumsden J, Fenton GW, Maisey MN, Lewis $\mathrm{P}$, et al. Positron emission tomography in male violent offenders with schizophrenia. Psychiatry Res 1997;68:111123.

86. Spalletta G, Troisi A, Alimenti S, di Michele F, Pau F, Pasini A, et al. Reduced prefrontal cognitive activation associated with aggression in schizophrenia. Schizophr Res 2001;50: 134-135.

87. Fjellvang M, Grøning L, Haukvik UK. Imaging violence in schizophrenia: a systematic review and critical discussion of the MRI literature. Front Psychiatry 2018;9:333.

88. Swanson JW, Swartz MS, Van Dorn RA, Volavka J, Monahan J, Stroup TS, et al. Comparison of antipsychotic medication effects on reducing violence in people with schizophrenia. Br J Psychiatry 2008;193:37-43.

89. Buckley PF, Kausch O, Gardner G. Clozapine treatment of schizophrenia: implications for forensic psychiatry. J Clin Forensic Med 1995;2:9-16.

90. Krakowski MI, Czobor P, Citrome L, Bark N, Cooper TB. Atypical antipsychotic agents in the treatment of violent patients with schizophrenia and schizoaffective disorder. Arch Gen Psychiatry 2006;63:622-629.

91. Swanson JW, Swartz MS, Elbogen EB. Effectiveness of atypical antipsychotic medications in reducing violent behavior among persons with schizophrenia in community-based treatment. Schizophr Bull 2004;30:3-20.

92. Lieberman JA, Stroup TS, McEvoy JP, Swartz MS, Rosenheck RA, Perkins DO, et al. Effectiveness of antipsychotic drugs in patients with chronic schizophrenia. N Engl I Med 2005; 353:1209-1223.

93. Tiihonen J, Wahlbeck K, Lönnqvist J, Klaukka T, loannidis JP, Volavka J, et al. Effectiveness of antipsychotic treatments in a nationwide cohort of patients in community care after first hospitalisation due to schizophrenia and schizoaffective disorder: observational follow-up study. BMJ 2006;333:224.

94. Buckley P, Citrome L, Nichita C, Vitacco M. Psychopharmacology of aggression in schizophrenia. Schizophr Bull 2011; 37:930-936.

95. Rabinowitz J, Avnon M, Rosenberg V. Effect of clozapine on physical and verbal aggression. Schizophr Res 1996;22: 249-255.

96. Volavka J, Zito JM, Vitrai J, Czobar P. Clozapine effects on hostility and aggression in schizophrenia. / Clin Psychopharmacol 1993;13:287-289.

97. Volavka J. The effects of clozapine on aggression and substance abuse in schizophrenic patients. J Clin Psychiatry 1999;60 Supp/ 12:43-46.

98. Allen MH, Currier GW, Carpenter D, Ross RW, Docherty JP. The expert consensus guideline series. Treatment of behavioral emergencies 2005. I Psychiatr Pract 2005;11 Supp/ 1:5-108; quiz 110-112.

99. Cramer JA, Rosenheck R. Compliance with medication regimens for mental and physical disorders. Psychiatr Serv 1998:49:196-201.

100. Valenstein M, Kavanagh J, Lee T, Reilly P, Dalack GW, Grabowski J, et al. Using a pharmacy-based intervention to improve antipsychotic adherence among patients with serious mental illness. Schizophr Bull 2011;37:727-736.

101. Park SC, Choi MY, Choi J, Park E, Tchoe HJ, Suh JK, et al. Comparative efficacy and safety of long-acting injectable and oral second-generation antipsychotics for the treatment of schizophrenia: a systematic review and meta-analysis. Clin Psychopharmacol Neurosci 2018;16:361-375.

102. Awad AG, Voruganti LL. Revisiting the 'self-medication' hypothesis in light of the new data linking low striatal dopamine to comorbid addictive behavior. Ther Adv Psychopharmacol 2015;5:172-178. 